\title{
VIDAS SECAS E O REGIONALISMO ${ }^{1}$
}

Cassiano Figueiredo Pereira ${ }^{2}$

\begin{abstract}
RESUMO
Este ensaio apresenta de uma maneira breve os elementos essenciais e particulares da obra Regionalista Vidas Secas, de Graciliano Ramos. O ensaio foi motivado pela disciplina de Literatura Brasileira Construção da Identidade Nacional, que possibilitou a compreensão dos aspectos essenciais do Regionalismo nordestino, o qual apresenta a descrição geográfica, a denúncia social, a linguagem típica da região e o êxodo rural. Graciliano traz elementos particulares por meio da linguagem, da forma como são tratadas as personagens, dos capítulos, sobretudo do universalismo que buscou transcender em sua obra.
\end{abstract}

PALAVRAS-CHAVE: regionalismo. universalismo. nordestino.

\begin{abstract}
This essay is a brief analysis of the Regionalist work of Graciliano Ramos entitled Vidas Secas, which presents some essential and particular elements. This essay emerged from the course "Literatura Brasileira - Construção da Identidade Nacional," which provided the opportunity to understand the essential aspects of Northeastern Regionalism, which exposes the geographic description, the social criticism, the typical language of the region and the exodus from the interior to the city. The author presents particular elements through the language, how he presents the characters in the narrative, the chapters and mainly the universalism which is highlighted in his work.
\end{abstract}

KEY WORDS: regionalism. universalism. Northeastern.

Graciliano Ramos, autor do livro Vidas Secas, foi um dos escritores que mais se destacaram no Romance Nordestino. Esse livro apresenta elementos essenciais para ser considerado com uma obra Regionalista, uma vez que ele expõe a seca, o homem nordestino hostilizado pelo ambiente; o êxodo rural, os retirantes que perambulam em busca de algo melhor na cidade grande, os problemas enfrentados pelo homem nordestino, a linguagem típica da região, a descrição geográfica e da realidade social. A obra, além de apresentar os aspectos essenciais, traz elementos particulares acerca da linguagem, dos capítulos, das personagens, da forma de narrar e do universalismo que o autor buscou transcender em sua obra.

Segundo Antonio Candido, em seu livro Ficção e Confissão, capítulo Cinquenta anos de Vidas secas (CANDIDO, 2006, p. 144), Graciliano só diz o essencial, isto é,ao narrar sua obra não faz somente a descrição do ambiente e das personagens em grandes detalhes como faziam outros autores.Ele só corta, nunca acrescenta, ao passo que faz o uso de poucos adjetivos, das orações assindéticas, de frases nominais curtas, do

\footnotetext{
${ }^{1}$ Ensaio motivado pela disciplina de Literatura Brasileira - Construção da Identidade Nacional. Orientação: Prof. ${ }^{\mathrm{a}}$ Dr. ${ }^{\mathrm{a}}$ Simone de Souza Braga Guerreiro.

${ }^{2}$ Graduando de Letras Português/Inglês pelo Instituto Superior Anísio Teixeira (ISAT)
} 
substantivo ao invés de adjetivo e a ausência de diálogos. Pode-se observar no capítulo I- Mudança (RAMOS, 2006), como ele descreve o espaço geográfico de uma maneira sucinta, "planície avermelhada", "catinga rala" e "lama seca e rachada". Não há uma descrição profunda, o leitor consegue captar rapidamente em seu imaginário o ambiente da seca. O uso do vocabulário típico da região é presente na obra a fim de ilustrar o ambiente nordestino. Tendo como exemplo a palavra "aió", uma bolsa trançada com fibra de caroá que é uma planta da caatinga nordestina, e cambaio, usado para designar uma pessoa com as pernas fracas.

Em Vidas Secas há ausência de diálogos, as vozes das personagens estão “costuradas” juntas a do autor, às vezes, não é perceptível se é o autor ou a personagem que está falando. É colocado em prática o uso do discurso indireto livre na narrativa, como também do narrador em terceira pessoa, isto é, aquele que enxerga pelos olhos da personagem. Além disso, de acordo com Antonio Candido (2006), os capítulos são curtos e independentes, não dependem um do outro para ter um sentido completo. Eles funcionam como "quadros", podem ser contemplados separadamente sem interferir na interpretação do leitor.

As personagens são tratadas de uma maneira desumana, ou seja, Graciliano quer mostrar a realidade do povo nordestino que vive na seca, onde são maltratados e que tentam sobreviver. Acredita-se que essa foi a forma que o autor encontrou de deixar nítido como os retirantes se sentem hostilizados na seca nordestina. Dessa maneira, Fabiano, Sinhá Vitória, Menino mais novo e o Menino mais velho são animalizados, e seus modos são similares a um animal. É notório, ao decorrer da trama, aspectos que são atribuídos a esses personagens para criar a ideia de animalizados, por exemplo, a Sinhá Vitória produz “sons guturais”;em outras palavras, não verbaliza, faz gestos e sons como um animal.O Fabiano se chama de homem e em seguida de "bicho", o que prevalece é a ideia de ser considerado um "bicho" porque ele carregava uma consciência de inferioridade. Ele se vê como um mísero "cabra", que vive numa terra e cuida de animais que não lhe pertencem, ou seja, sobrevive dependendo de migalhas, se sente inferior e envergonhado, por isso se considera um "bicho" e não um homem. Nessa passagem: "Parecia um macaco" (RAMOS, 2006, p.08), pode-se observar como é reforçada essa ideia. Nota-se nesse fragmento, "Ele, a mulher e os filhos já tinham-se habituado à camarinha escura, pareciam ratos" (RAMOS, 2006, p. 07) que as personagens a todo momento são comparadas a animais e não apresentam muitas 
características humanas, são sempre inferiorizadas e lembradas do lugar miserável de origem.

Em contraste, o autor não segue a lógica de atribuir aspectos animais, mas sim humanos à cachorra Baleia. Ela é humanizada, ou seja, apresenta sensações humanas. No fragmento: "Ela era como uma pessoa da família: brincavam juntos os três, para bem dizer não se diferenciavam (...)" (RAMOS, 2006, p. 39), nota-se que a cachorra era considerada como parte da família e não havia diferença entre eles, todos desfrutam das mesmas sensações:o afeto e a alegria de viverem juntos. No último parágrafo, capítulo IX(RAMOS, 2006, p.42), Baleia ao se sentir distante da vida, próxima de morrer, começa a idealizar o lugar para onde irá viver após a morte, conforme a passagem “Acordaria feliz, num mundo cheio de preás. (...) num pátio enorme, num chiqueiro enorme" (RAMOS, 2006, p. 42). A partir desse excerto, podemos compreender como essa personagem apresenta características humanas, pois ela delira ao morrer e idealiza um paraíso como se fosse uma recompensa pós-morte. Diante disso, pode-se inferir que os papéis são invertidos, enquanto a cachorra é humanizada, Fabiano, sua mulher e seus filhos são vistos como animais.

A seca e a miséria são tratadas de maneira explícita, representadas em uma vida literalmente seca, sem vigor e sem água potável para sobreviver. Essa é a descrição da realidade que caminha junto à denúncia social; o autor, ao mesmo tempo que expõe a realidade, faz crítica social. Isto transcorre de uma maneira muito clara e objetiva, por meio de uma linguagem direta e compreensível.

O Regionalismo nordestino é muito bem representado em Vidas Secas, o autor atende aos aspectos para ser considerado como tal e consegue trazer características particulares a sua obra. Em outras palavras, Graciliano não só traz os elementos essenciais de uma obra Regionalista, como também ressalta a visão dramática de um mundo opressivo, onde há pessoas que têm muito e outras que vivem de migalhas. Nesse sentido, podemos compreender o universalismo, ao retratar as questões humanas, não somente do nordeste brasileiro, mas de uma forma abrangente. A miséria e a opressão são fatos atuais, e até hoje encontramos pessoas em situações desumanas.Por fim, Graciliano consegue ultrapassar a região nordestina e atinge o mundo com o seu universalismo, com isso pode-se perceber que a pobreza existe em todos os lugares, e está presente em todos as épocas. Muitas das vezes, a miséria é tanta que o ser humano 
é tratado como um "bicho". O aspecto do universalismo é o que torna sua obra única e destacando-se dos outros autores regionalistas.

\section{REFERÊNCIAS BIBLIOGRÁFICAS}

RAMOS, Graciliano. Vidas Secas. Rio de Janeiro: Record, 2006.

CANDIDO, Antonio. Ficção e Confissão. Rio de Janeiro: Ouro sobre Azul, 2006. 